DOI: $10.2478 /$ achi-2020-0007

\title{
TOXICITY ASSESSMENT OF ARSENITE AND \\ ITS RELATIONSHIP WITH ARSENIC \\ POLLUTED AREA OF TARNIȚA: THE \\ PROTECTIVE EFFECT OF GLUTATHIONE
}

\author{
Alina Butnariu ${ }^{\mathrm{a}}$, Maria-Magdalena Zamfirache ${ }^{\mathrm{a}}$ and \\ Gabi Drochioiu $^{b^{*}}$
}

\author{
${ }^{a}$ Faculty of Biology, “Al. I. Cuza” University Iasi, 20A Carol I, Iasi- \\ 700505, Romania \\ ${ }^{b}$ Faculty of Chemistry, “Al. I. Cuza” University Iasi, 11 Carol I, Iasi- \\ 700506, Romania
}

\begin{abstract}
Tailings deposits in Tarnița, Suceava County affect the soils around. These large sterile dumps are highly contaminated with arsenic and heavy metals. The effect of various concentrations of arsenite and arsenate on wheat seeds and seedling growth within several germination experiments was investigated in order to assess potential individual toxicity of arsenic released from the sterile dumps. Samples of spring wheat (Triticum aestivum L.) seeds were used to investigate the effect of arsenic at seed level and its influence on the resulting plantlets. The effect of glutathione on sodium arsenite toxicity in wheat during the germination process was also studied. Arsenite $\left(\mathrm{NaH}_{2} \mathrm{AsO}_{3}\right)$ concentrations ranged from $0.25 \mathrm{mM}$ to $5 \mathrm{mM}$, while the concentrations of arsenate $\left(\mathrm{NaH}_{2} \mathrm{AsO}_{4}\right)$ and glutathione $(\mathrm{GSH})$ solutions were $1 \mathrm{mM}$ and $10 \mathrm{mM}$, respectively. Germination rate of wheat seeds decreased significantly with increasing arsenite concentrations; it decreased from 100\% (control) to only $24 \%$, when a $5 \mathrm{mM}$ arsenite concentration was reached. A similar trend was observed for total shoot heights and masses of wheat seedlings by increasing arsenite concentrations. Interestingly, GSH alone slightly decreased the average heights and mass of shoots as compared with the control carried out with distilled water (Control: $9.04 \mathrm{~cm}$ and $2.34 \mathrm{~g}$; GSH: $7.18 \mathrm{~cm}$ and $1.78 \mathrm{~g}$ ). However, GSH completely recovered the germination of $0.25 \mathrm{mM}$ arsenite-
\end{abstract}

\footnotetext{
* Gabi Drochioiu, e-mail: gabidr@uaic.ro
} 
A. Butnariu et al.

intoxicated seeds (no GSH: $4.39 \mathrm{~cm}$ and $1.29 \mathrm{~g}$; GSH: $7.24 \mathrm{~cm}$ and $1.81 \mathrm{~g}$ ). Moreover, a more concentrated arsenite solution $(0.826 \mathrm{mM})$ almost completely inhibited the wheat germination $(0.32 \mathrm{~g}$ of shoots with an average height of 0.99 $\mathrm{cm})$, while GSH partially restored both germination parameters $(0.84 \mathrm{~g}$ and 2.45 $\mathrm{cm}$, respectively). Briefly, wheat germination approaches may be authentic and inexpensive toxicity screening methods of arsenic in the environment.

Keywords: Arsenite toxicity; Tarniţa polluted area; Glutathione; Germination test; Wheat

\section{Introduction}

A very intense mining activity in Tarnița area, Suceava county, northeastern Romania induced an intense environment pollution. ${ }^{1,2}$ Arsenic speciation in Tarniţa area and its risk assessment was also highlighted. ${ }^{3}$ Some other toxic elements, such as $\mathrm{Cu}, \mathrm{Pb}, \mathrm{Cd}, \mathrm{Zn}, \mathrm{Fe}$, etc. were found as major factors that promote the environmental pollution of Tarniţa area. However, arsenic in sterile and soils can be highly reactive and mobile in the arsenite or arsenate form, resulting in the formation of metal arsenates. ${ }^{4}$ Arsenic was found in water and soil around some closed mines as arsenate ions (oxidation state V), whereas arsenite (oxidation state III) in certain anaerobic conditions. ${ }^{5}$

Arsenic inactivates about 200 enzymes, including those involved in cellular energy pathways and DNA synthesis and repair. ${ }^{6}$ Arsenic poisoning is generally associated with nausea, vomiting, abdominal pain as well as severe diarrhea. This element induces oxidative stress in plants and reduces the nutritive value of the harvesting products. ${ }^{7}$

Arsenic uptake in crop plants from the arsenic-contaminated irrigation water was also investigated. ${ }^{8}$ Arsenic contamination in Bangladesh was studied using the geographic information system. ${ }^{9}$ Several authors showed that arsenic in soil and sediments is usually associated with aluminum, iron, manganese and sulfates, phosphates or carbonates, and such ions are essential for the distribution and mobility of arsenic. ${ }^{10}$ 
Groundwater and rivers may become contaminated naturally from mining or agriculture. $^{6}$

Arsenite is considered to be more toxic and mobile than arsenate to plants; arsenate uncouples phosphorylation and inhibits the uptake of phosphates. ${ }^{11}$ In fact, arsenate ions are uptaken by high-affinity phosphate transporter in plants and about $95 \%$ of it is reduced to more toxic arsenite by cytoplasmic or nucleus arsenate reductase. ${ }^{12,13}$

Because wheat seeds are sensitive to toxic metal and metalloid ions in general, parameters such as shoot heights and root lengths recorded after wheat germination can be indicators of choice for arsenic toxicity. ${ }^{14}$ Therefore, this study aims to evaluate the germination performance of wheat seeds under arsenic pollution through a facile incubation method in Petri dishes with a seven-day incubation period. Arsenic concentrations lower than those estimated in the tailings dumps, in Tarniţa area, have been found to have devastating effects on plant development and growth.

\section{Results and Discussion}

Experiment 1. A higher toxicity of the sterile from one of the Tarniţa tailings dumps and the possibility to decontaminate using water in order to dissolve and remove soluble contaminants was noticed (Figure 1). The remaining residue proved to be harmless. Thus, the tailings extracted two or three times with $10 \mathrm{~mL}$ of distilled water did not inhibit the seeds germination or growth of wheat seedlings, as seen from the plantlets average height and their shape (Control, $11.3 \mathrm{~cm}$; Lots with $1 \mathrm{~g}$ of toxic sterile, $1.6 \mathrm{~cm}$; Lots washed with $2.10 \mathrm{~mL}$ water, $10.4 \mathrm{~cm}$; Lots washed with $3 \cdot 10 \mathrm{~mL}$ water, $10.9 \mathrm{~cm}$ ). Meanwhile, the concentrations of such contaminants in the sterile of the dumps were measured. ${ }^{15}$ The reported 
concentrations were $676 \mathrm{mg} / \mathrm{kg}$ arsenic, 3,119 mg/kg copper, and 2,672 $\mathrm{mg} / \mathrm{kg}$ lead, whereas other elements were either less toxic (Ba, $\mathrm{Zn}$ ) or were considered as trace elements.

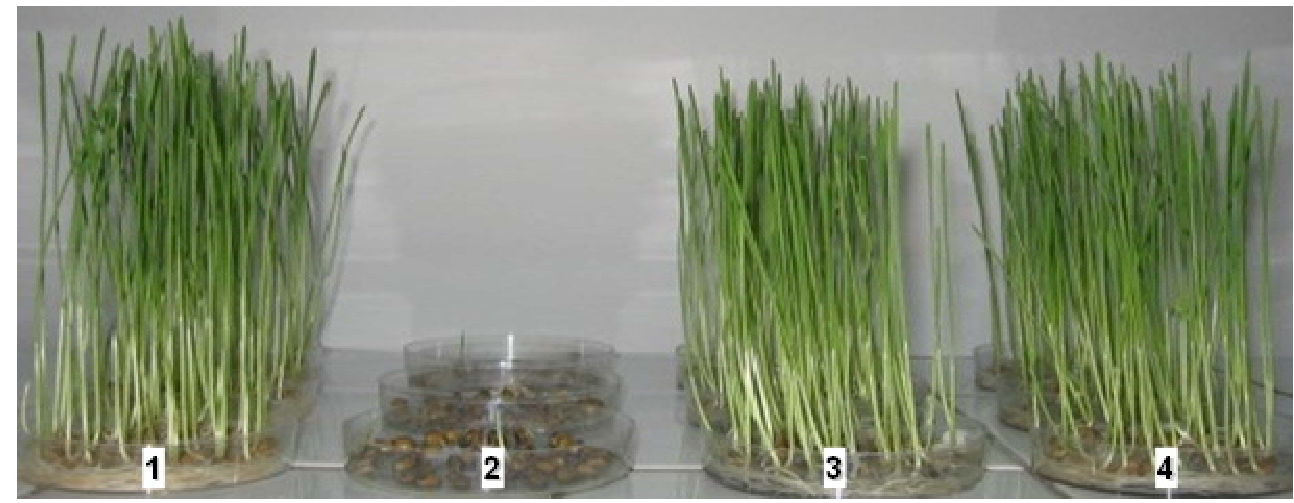

Figure 1. The effect of sterile material collected from one of Tarniţa tailings dumps on the germination of wheat caryopses. The measurements were made after the 7 th day of germination: 1 - Control with $5 \mathrm{~mL} \mathrm{H}_{2} \mathrm{O} ; 2-1 \mathrm{~g}$ of sterile material; $3-1 \mathrm{~g}$ of sterile material washed with $2 \cdot 10 \mathrm{~mL}$ water; $4-1 \mathrm{~g}$ of sterile material washed with $3 \cdot 10 \mathrm{~mL}$ water.

Therefore, we hypothesized that arsenic present in the tailings as arsenate or arsenite may have additive toxicity on plants to that of other toxic elements such as copper, lead, iron, aluminum. Therefore, in order to study the contribution of arsenic to the overall toxicity of the tailings, it was necessary to determine the toxic effect of some arsenite- or arsenatecontaining solutions at various concentrations. 

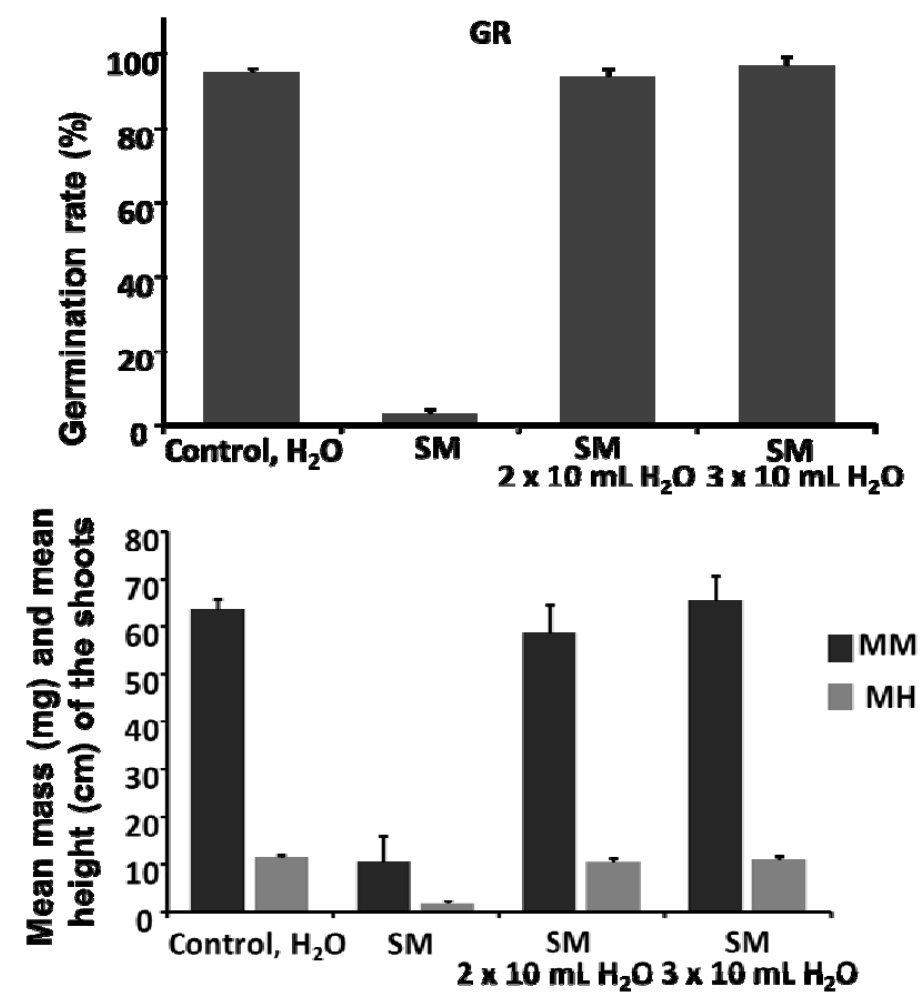

Sterile material (SM) unwashed and washed $(2 x, 3 x)$ with $\mathrm{H}_{2} \mathrm{O}$

Figure 2. The effect of the material collected from the tailings dump on the germination of Triticum aestivum $L$. species. Data were collected in the 7th day of the experiment (GR - germination rate in \%; MM - Mean mass of lot shoots in mg; MH - Mean height of the resulted seedlings in $\mathrm{cm}$ ).

Experiment 2. Germination experiments using wheat caryopses showed that arsenite ions at concentrations lower than those in the sterile materials of Tarniţa $(0.676 \mathrm{mg} / \mathrm{g}$ As; 0.09 milimoles $/ \mathrm{g})$ are highly toxic to wheat seeds and almost completely inhibited both germination and growth of seedlings of wheat caryopses (Fig. 3). In this experiment concentrations of arsenite solutions ranging from $0.25 \mathrm{mM}$ to $5 \mathrm{mM} \quad(1.25$ micromoles/sample to 25 micromoles/sample) were used. 


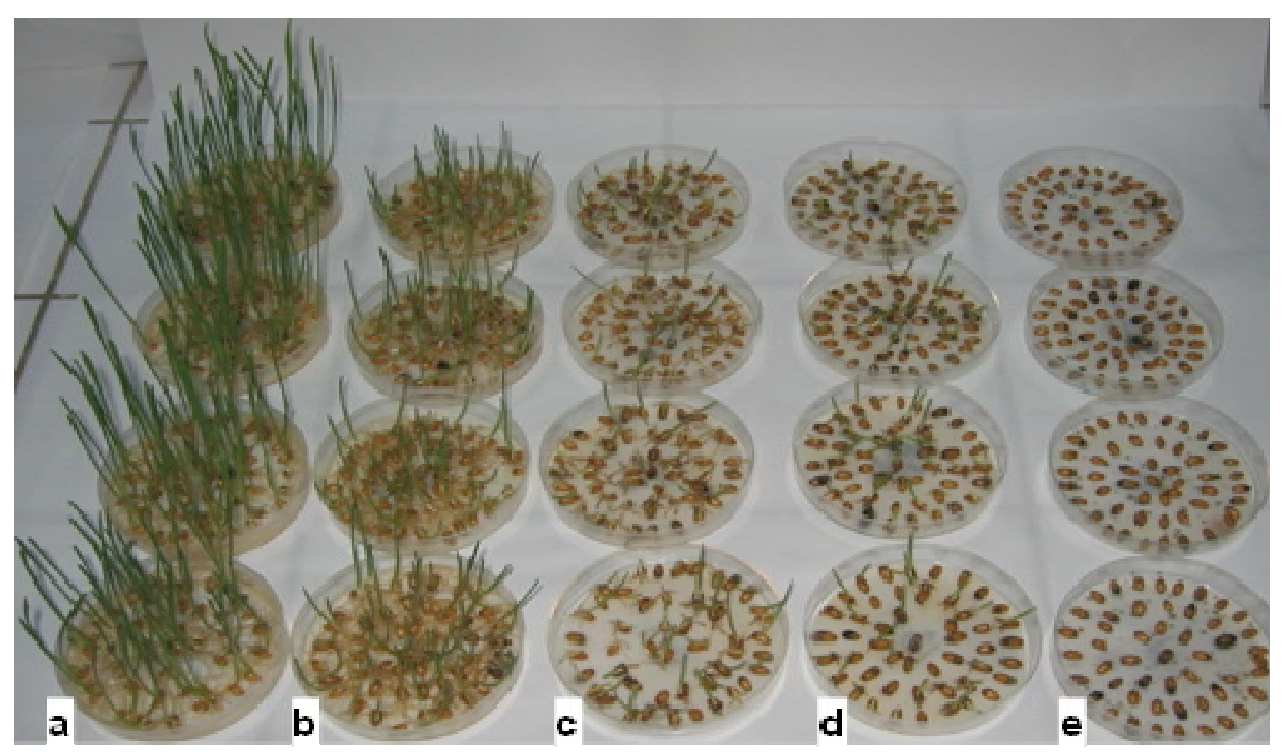

Figure 3. Effect of sodium arsenite on wheat seed germination. Seedlings resulted after 7 days of treatment. Arsenite concentrations: a) Control with $\mathrm{H}_{2} \mathrm{O}$; no arsenite; b) $0.25 \mathrm{mM}$; c) $0.826 \mathrm{mM}$; d) $1.8 \mathrm{mM}$; and e) $5 \mathrm{mM}$.

The germination rate ( $\%$ germinated caryopses after 7 days) decreased from $100 \%$ (control) to $96 \%\left(\mathrm{AsO}_{3}{ }^{3-}, 0.25 \mathrm{mM}\right.$ ), but continuously decreased up to $24 \%$ as the concentration of arsenite ions increased from $0.25 \mathrm{mM}$ to $5 \mathrm{mM}$ (Fig. 3). Germination rate decreased linearly with increasing arsenite concentration (Fig. 4). However, the shoot heights and masses decreased exponentially, suggesting that, following germination, seedlings are continuously impaired. These data could be explained by inhibition of many SH-groups containing enzymes. ${ }^{16} \mathrm{We}$ have noticed that under the action of arsenite, the size of the radicles reduced significantly, until disappearing. 

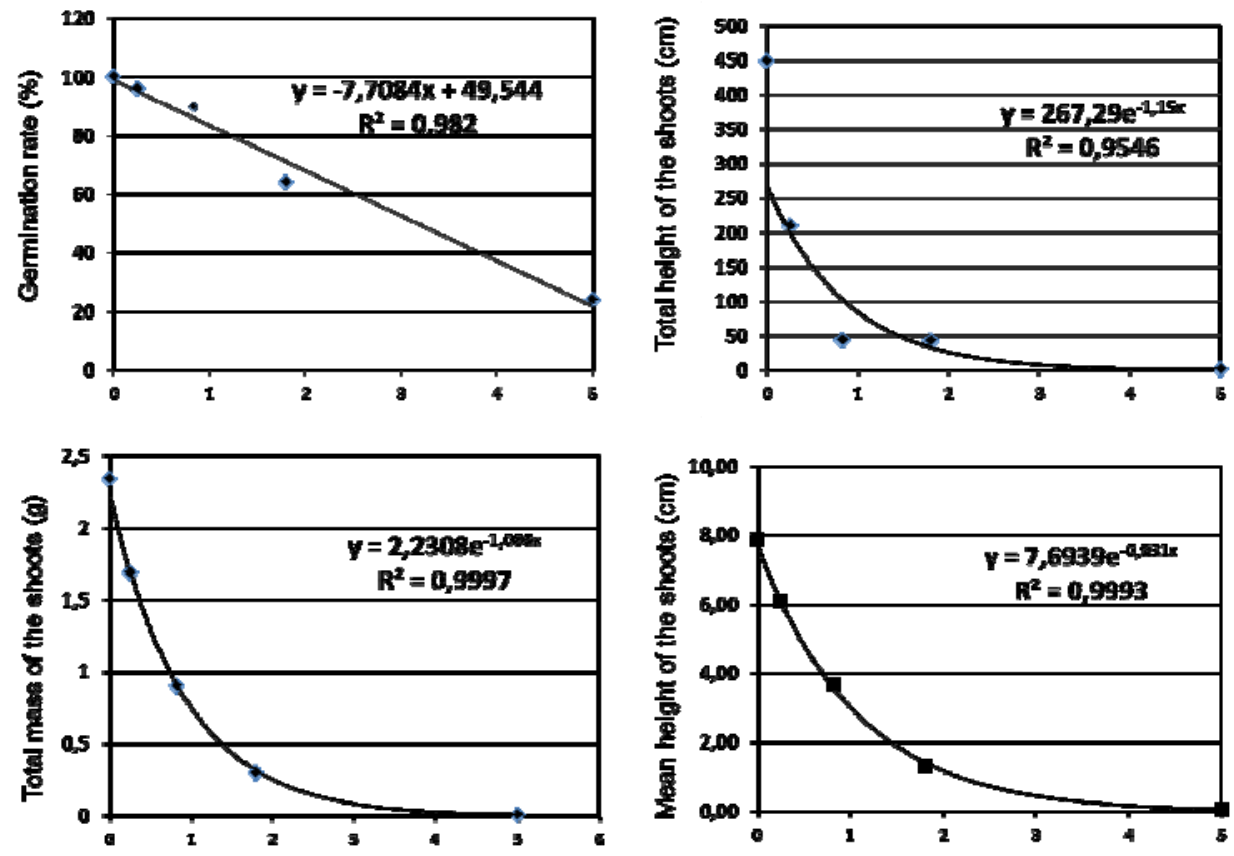

Arsenite concentration (mM)

Figure 4. The relationship between the wheat germination parameters and arsenite concentration.

Experiment 3. In the next experiment, the role of glutathione on the toxicity of arsenite ions during germination tests, using wheat caryopses, was investigated (Fig. 5). A decrease in the germination parameters (percent of germinated seeds, average weight and length of plantlets) was noticed when the seeds were treated with slightly higher concentrations of sodium arsenite $(0.826 \mathrm{mM}$ and $1.8 \mathrm{mM})$ in the presence of glutathione $(10 \mathrm{mM})$, proving that the thiol group could be blocked by arsenic. However, glutathione had a protective role on wheat seed germination in the presence of toxic arsenite, probably due to its own thiol group which binds to arsenic atom. 
While a $1.8 \mathrm{mM}$ arsenite solution reduced the germination rate of wheat seeds to $64 \%$ (Fig. 4), the $10 \mathrm{mM}$ glutathione treatment solution increased the germination rate by $36 \%$ (Fig. 5). Significant effects were noticed when the total masses and mean heights of the resulted seedlings had been considered. Mean height of the resulted seedlings decreased with 0.42 units when a toxic $1.8 \mathrm{mM}$ arsenite solution was used for the treatment and compared with a lower concentration $(0.826 \mathrm{mM})$. The $10 \mathrm{mM}$ glutathione solution proved to have a slightly protective effect. The total mass of the resulted shoots decreased with 0.26 units as well.
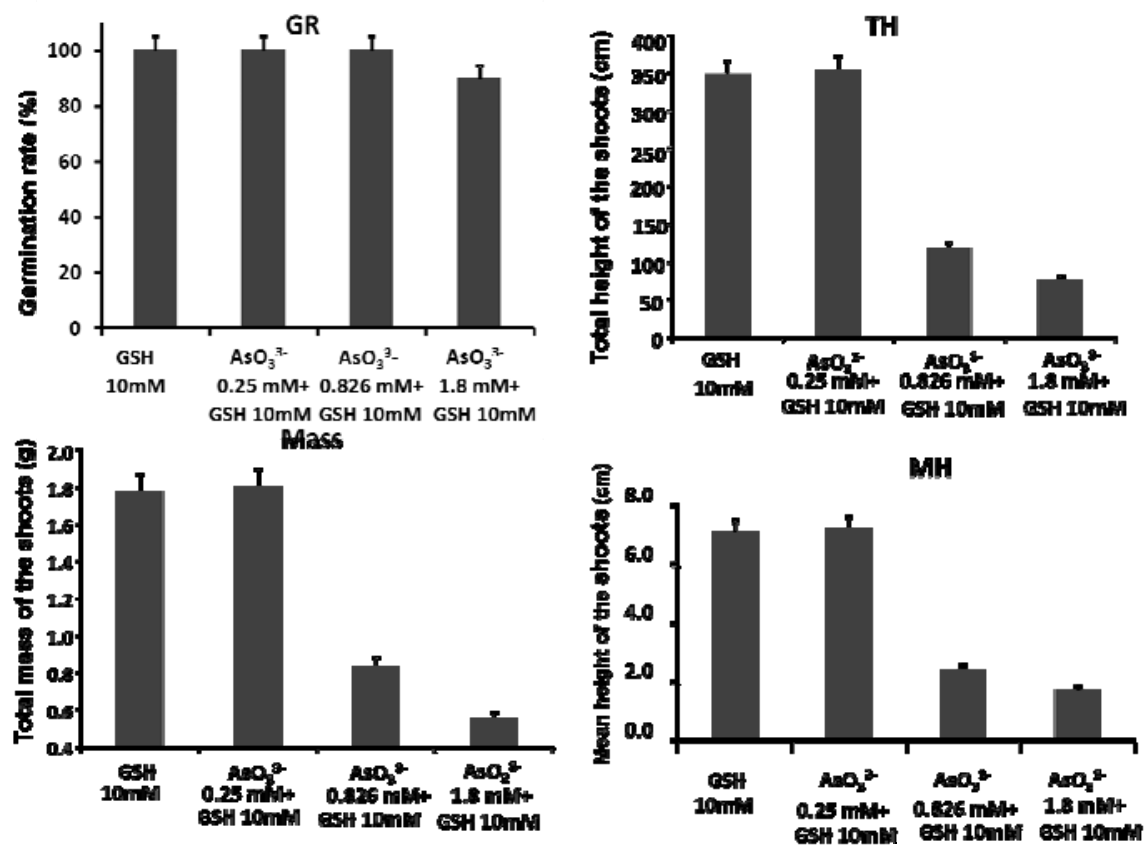

Figure 5. The protective role of glutathione against arsenite toxicity during the germination of Triticum aestivum L. species. Data were collected in the 7th day of the experiment (GR germination rate; Mass - Total mass of the shoots in lots; $\mathrm{TH}$ - Total height; $\mathrm{MH}$ - Mean height of the resulted seedlings).

Experiment 4. In the fourth experiment, the comparative effect of both arsenate and arsenite ions during germination tests on wheat caryopses 
was investigated (Fig. 6). The toxic activity of the arsenite ion was compared with that of the arsenate ion. The last one showed a higher toxicity than arsenite, contrary to the literature data (Fig. 6). Thus, compared to the control samples, the number of seedlings decreased from an average of 48 seedlings per lot to only 40 . In addition, the total heights of the shoots decreased by $80 \%$, from $517.3 \mathrm{~cm}$ in the control lots to $105.9 \mathrm{~cm}$ in the lots treated with arsenate (Fig. 7). Comparatively, arsenite did not affect the number of plants formed. However, the total height of the seedlings decreased to only $59 \%$, from $517.3 \mathrm{~cm}$ to $306.2 \mathrm{~cm}$. Glutathione has shown a protective role, the decrease in the height of the plantlets being not significant (498 cm compared with $517 \mathrm{~cm}$ ). The average height of the resulted seedlings was recovered by $63 \%$ when sodium arsenite was associated with glutathione, namely from $6.29 \mathrm{~cm}$ (no GSH) to $9.96 \mathrm{~cm}$ (with GSH). An average of recovered mass by $66 \%$ on adding glutathione during the seed germination in the presence of arsenite ions was also noticed.

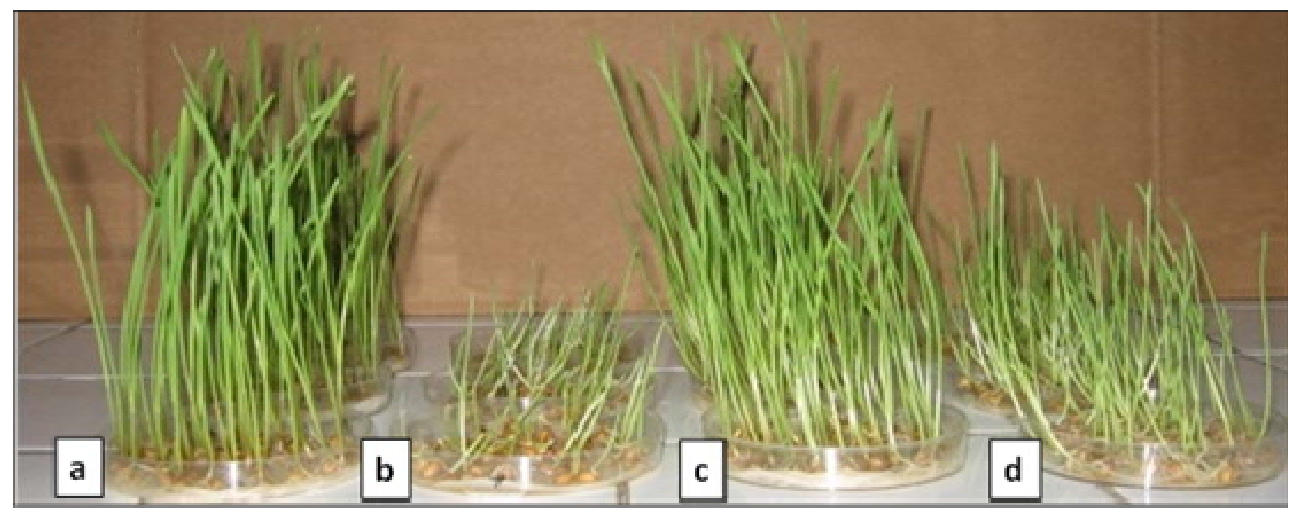

Figure 6. Effect of arsenate and arsenite ions on wheat seed germination in the presence of glutathione. Seedlings resulted after 7 days of treatment. Treatment solutions: a) Control with $\mathrm{H}_{2} \mathrm{O}$; b) $\mathrm{NaH}_{2} \mathrm{AsO}_{4}, 1 \mathrm{mM}$; c) $\mathrm{NaH}_{2} \mathrm{AsO}_{3}, 1 \mathrm{mM}+\mathrm{GSH}, 10 \mathrm{mM}$; and d) $\mathrm{NaH}_{2} \mathrm{AsO}_{3}, 1$ $\mathrm{mM}$. 

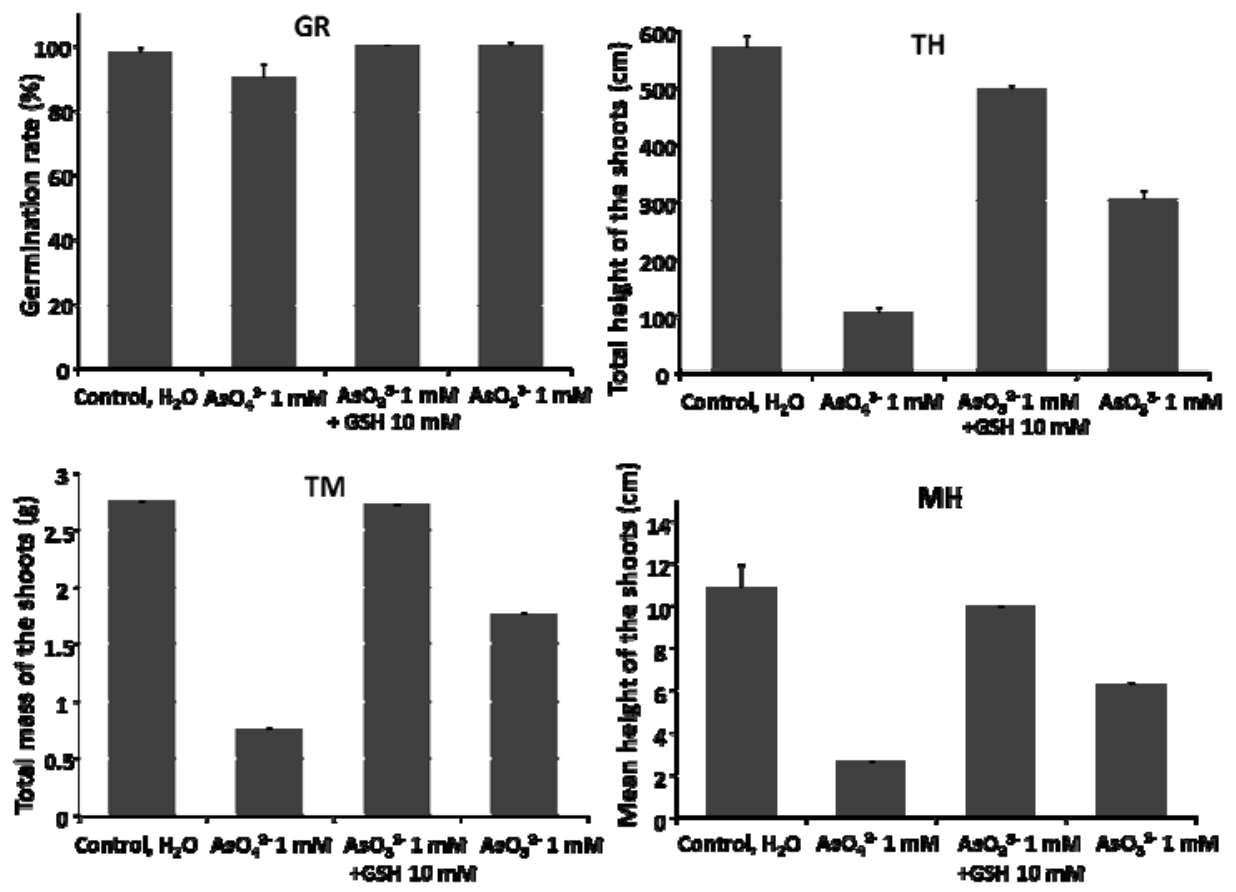

Arsenate $1 \mathrm{mM}$ and Arsenfte $1 \mathrm{mM}+$ GSH $10 \mathrm{mM}$

Figure 7. The comparative effect of arsenate and arsenite ions during the germination of Triticum aestivum L. species. Data were collected in the 7th day of the experiment (GR germination rate; TM - Total mass of lot shoots; $\mathrm{TH}$ - Total height; $\mathrm{MH}$ - Mean height of the resulted seedlings).

\section{Experimental}

Materials. All reagents used to carry out chemical and biological experiments, were of analytic purity and the solutions were prepared with MilliQ grade water $(18.2 \mathrm{M} \Omega \cdot \mathrm{cm})$. Arsenic trioxide, sodium arsenate dibasic heptahydrate, sodium hydroxide and glutathione were purchased from Merck (Darmstadt, Germany). Arsenic trioxide was dissolved in the corresponding sodium hydroxide solutions to form arsenite solutions used in experiments. Biological material consisted in wheat seeds were from Solaris Plant S.R.L. Bucharest. The weight of 1000 dried caryopses was $42.4 \mathrm{~g}$. 


\section{Treatment solutions and germination tests}

Experiment 1 refers to a sterile material collected from one of the tailings dumps, which was used without any treatment or was washed many times with distilled water to remove the toxic contaminants. The samples consisted of 50 wheat seeds were uniformly deposited on double filter paper in Petri dishes together with $1 \mathrm{~g}$ of finely dispersed sterile material (Fig. 8). A set of sterile samples (1 $\mathrm{g}$ each) were previously transferred into test tubes and washed once, twice, and three times with $10 \mathrm{~mL}$ of distilled water in order to release the toxicants.

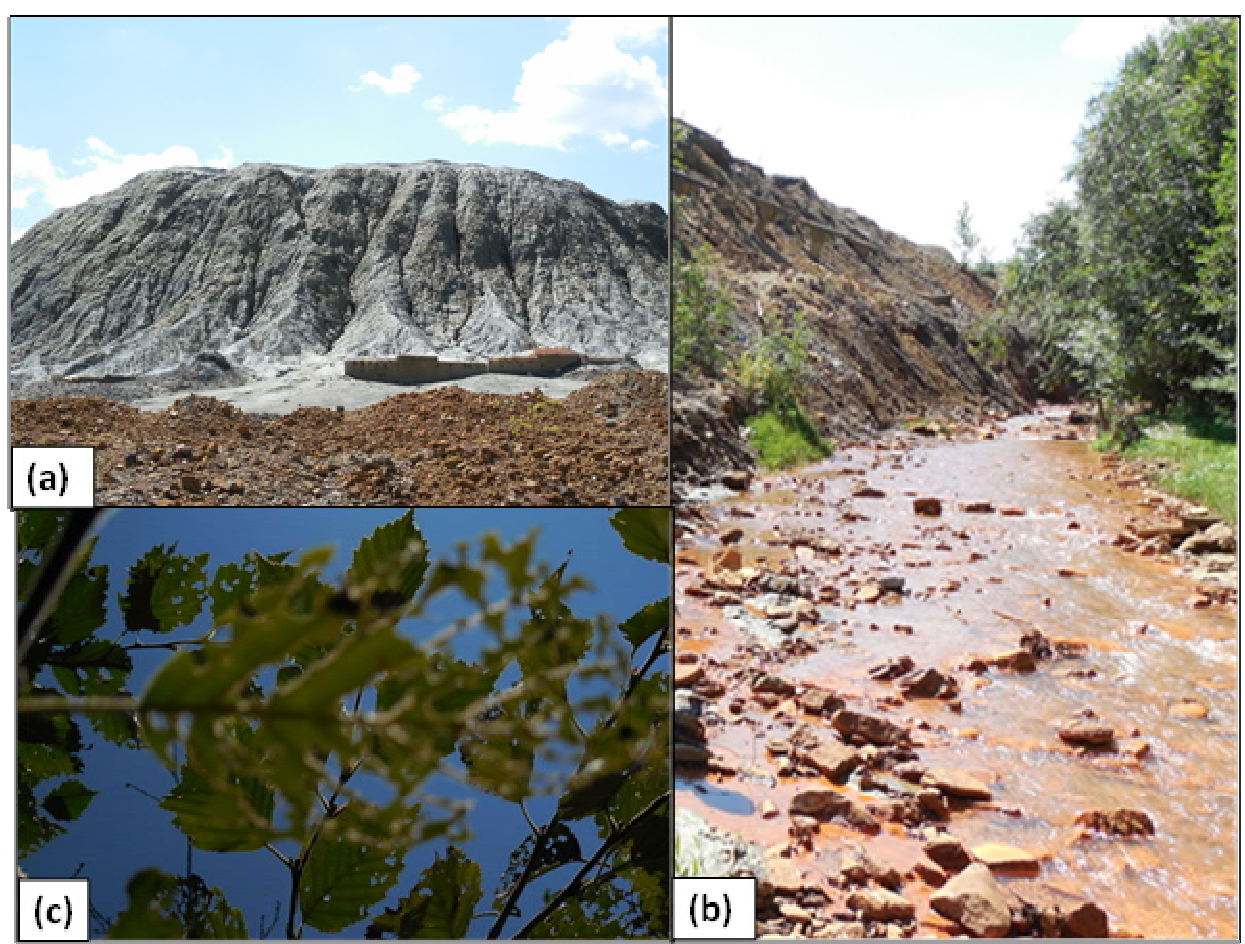

Figure 8. Sampling points in the Tarnița-Suceava area, Romania: (a) Tailings dump; (b) Contaminated Tărnicioara river (about $50 \mathrm{~m}$ away from the tailings dump); (c) Possible effect of arsenic and heavy metals on plant leaves in polluted Tarnița area.

For testing the harmful action of the tailings on the wheat seeds, lots of 50 seeds were treated with $5 \mathrm{~mL}$ of distilled water (control) for one hour 
in 180/18 mm test tubes, with discontinuous shaking, and then deposited in Petri dishes. The control experiments were performed in the first three Petri dishes in the absence of any sterile material. Conversely, the next three dishes, each containing $1 \mathrm{~g}$ of sterile, which was not extracted with distilled water, were used to establish the heavy metals impact on plant development. The next seed lots were put to germinate on filter paper containing $1 \mathrm{~g}$ of sterile material, which was twice and three times washed with $10 \mathrm{~mL}$ of distilled water $\left(2 \cdot 10 \mathrm{~mL} \mathrm{H}_{2} \mathrm{O}\right.$ and $3 \cdot 10 \mathrm{~mL} \mathrm{H} \mathrm{H}_{2} \mathrm{O}$, respectively). The energy and germination rate as well as the height and mass of the resulting seedlings were determined. ${ }^{17}$

Experiment 2. To determine the effect of arsenic from mining wastes from Tarniţa on the germination of wheat caryopses and the development of Triticum aestivum L. seedlings, sodium arsenite stock solutions were prepared in four replications as follow:

1) $0.25 \mathrm{mM} \mathrm{NaH}_{2} \mathrm{AsO}_{3}$; 2) $0.826 \mathrm{mM} \mathrm{NaH}_{2} \mathrm{AsO}_{3}$; 3) $1.8 \mathrm{mM} \mathrm{NaH}_{2} \mathrm{AsO}_{3}$; 4) $5 \mathrm{mM} \mathrm{NaH}_{2} \mathrm{AsO}_{3}$.

These four sodium arsenite solutions of the above-mentioned concentrations $(0.25 \mathrm{mM}, 0.826 \mathrm{mM}, 1.8 \mathrm{mM}$ and $5 \mathrm{mM})$ were used in the germination tests on Triticum aestivum $L$. caryopses ( $5 \mathrm{~mL} / 50$ wheat seeds). Distilled water (no $\mathrm{NaH}_{2} \mathrm{AsO}_{3}$ ) was considered a control sample.

Experiment 3. The protective effect of glutathione on the germination of Triticum aestivum L. caryopses within the arsenite toxicity was investigated using stock solutions of sodium arsenite and glutathione, prepared in four replications:

1) $5 \mathrm{~mL}$ GSH $10 \mathrm{mM}$ (was considered as control sample);

2) $5 \mathrm{~mL}$ of $0.25 \mathrm{mM} \mathrm{NaH} \mathrm{AsO}_{3}+10 \mathrm{mM} \mathrm{GSH}$;

3) $5 \mathrm{~mL}$ of $0.826 \mathrm{mM} \mathrm{NaH}_{2} \mathrm{AsO}_{3}+10 \mathrm{mM} \mathrm{GSH}$; 
4) $5 \mathrm{~mL}$ of $1.8 \mathrm{mM} \mathrm{NaH} \mathrm{AsO}_{3}+10 \mathrm{mM} \mathrm{GSH}$. In the treatment schemes (2), (3) and (4) $2.5 \mathrm{~mL}$ of $0.5 \mathrm{mM}, 2.5 \mathrm{~mL}$ of $1.652 \mathrm{mM}$ and $3.6 \mathrm{mM}$ $\mathrm{NaH}_{2} \mathrm{AsO}_{3}$, respectively, were pipetted into the corresponding test tubes and stirred for $30 \mathrm{~min}$, followed by the addition of $2.5 \mathrm{~mL}$ of $20 \mathrm{mM} \mathrm{GSH}$ and stirring from time to time for other $30 \mathrm{~min}$.

Experiment 4. The comparative effect of arsenate and arsenite toxicity on the germination of Triticum aestivum $L$. caryopses, and the protective role of glutathione over arsenite toxicity was assessed. The samples of sodium arsenate, sodium arsenite and glutathione, were prepared in triplicate and used as follow:

1) $5 \mathrm{~mL}$ of $\mathrm{H}_{2} \mathrm{O}$ (control);

2) $5 \mathrm{~mL}$ of $1 \mathrm{mM} \mathrm{NaH} \mathrm{AsO}_{4}$;

3) $2.5 \mathrm{~mL}$ of $2 \mathrm{mM} \mathrm{NaH} \mathrm{AsO}_{3}$ for $30 \mathrm{~min}$; then $2.5 \mathrm{~mL}$ of $20 \mathrm{mM}$ GSH for the next $30 \mathrm{~min}$ (that means $5 \mathrm{~mL}$ of $1 \mathrm{mM} \mathrm{NaH}_{2} \mathrm{AsO}_{3}+10 \mathrm{mM}$ GSH);

4) $5 \mathrm{~mL}$ of $1 \mathrm{mM} \mathrm{NaH} \mathrm{AsO}_{3}$.

Germination tests. Biological tests using standard stock solutions were performed in triplicate or tetraplicate. Lots of 50 wheat caryopses were introduces into sufficiently large test tubes $(180 \times 18 \mathrm{~mm})$ to allow mixing and then for each sample the treatment solution was added. The mixture was subjected to incubation for one hour while intermittently stirring. This period of time was sufficient for soaking the caryopses with water (control) or extraction solutions. After one hour, caryopses together with the treatment solutions were laid as uniformly as possible in 9-cm diameter Petri dishes, on double filter paper (Whatman 181). On days 1, 2 and 3, Petri dishes were left covered. In the first three germination days, the Petri dishes were uncovered, and the wheat caryopses were sprayed with 2-5 of 
$\mathrm{mL}$ of bidistilled water, depending on the level of the liquid in the Petri dishes and kept at room temperature. The germination process in the presence of treatment solutions lasted for 7 days.

The first count was made after three days, when were determined the number of germinated caryopses (energy of germination, GE, expressed as a percentage). A second measurement was performed after seven days, when the number of seedlings, number of germinated caryopses but undersized properly (germination rate, GR, expressed as a percentage) and number of dead caryopses were determined in each Petri dish. For each seedling $(\mathrm{H} \geq$ $0.5 \mathrm{~cm}$ ), the stem with leaves (shoots) was harvested from the bottom of the caryopses. The results were expressed as the average weight (MM, mg) and the average height of seedlings $(\mathrm{MH}, \mathrm{cm})$.

Sampling. Samples of sterile were collected from the sterile dump (Fig. 8). The collected samples proved to contain large amounts of arsenic and heavy metals, elements which influenced much the germination of common wheat species. Analogously, Triticum aestivum L. was used in this study as an indicator of toxicity. The arsenite and heavy metal ions from the contaminated environment may penetrate the plants, either by absorption from soil or by the aerial parts of the plant, as a result of the deposition of particulate contaminants. Typically, the amount of these toxic elements penetrating through the aerial parts is much lower, while the plants are usually washed before being consumed. ${ }^{18}$ However, part of heavy metals and metalloids such as arsenic may accumulate in plants and can be recovered from the harvested biomass, reduced as a biocompost, by compaction or by heat treatments.

Statistics. The collected data were validated using the Tukey test. ${ }^{19}$ A $95 \%$ confidence interval was used to determine error. The standard 
deviation of triplicate or tetraplicate values was calculated for each treatment. Besides, ANOVA was also used to determine the significance of results.

Discussion. The effects of arsenite ions on wheat seed germination, early seedling growth, shoot length and mass as well as the protective role of glutathione against arsenic toxicity have been investigated. A commercial variety of wheat seeds (Triticum aestivum L.) was first used to demonstrate the toxicity of arsenic-containing sterile materials from Tarniţa, Suceava County in germination biotests. Furthermore, the toxic ions found in soils located around the closed mines such as those from Tarniţa area can be easily removed. In addition, the possibility of inhibiting their toxicity by using glutathione was explored. Experiments have shown that glutathione at a concentration of $10 \mathrm{mM}$ can be used as a protective agent against arsenite dependent toxicity during wheat seed germination and seedling development.

Germination experiments proved to be reliable tool in the investigation of plant responses to toxicity of various substances. ${ }^{17}$ Recently, the response of wheat during seed germination to different doses of herbicides was investigated using materials such as paper, sand or agaragar. We also adopted this simple, low costly and reproducible procedure recommended by Weiss et al. ${ }^{17}$ and customize it to wheat seeds in order to test the toxicity of environmental contaminants such as arsenic and heavy metals. It is well-known that arsenic long-term exposure can lead to thickening of the skin, abdominal pain, darker skin, diarrhea, heart disease, and even cancer. ${ }^{6}$ Therefore, its levels in water is recommended to be less 
than $10-50 \mu \mathrm{g} \mathrm{L}^{-1}$. Nevertheless, arsenic contamination can be generated also by consuming plants grown on contaminated soils.

\section{Conclusions}

Interaction between glutathione and sodium arsenite was investigated during the seed germination of Triticum aestivum $L$. test species and plant growth. Glutathione exhibited protection against the sodium arsenite toxicity and had a protective role on seedling growth. However, the data analysis that converge from these typical measurable parameters, used to establish a relationship of glutathione with arsenite ions by germination tests, is more complex and should be deeply investigated. Arsenic as both arsenite and arsenate ions has been shown to be very harmful to wheat. Therefore, the germination tests could be trustworthy markers for arsenic toxicity.

\section{Acknowledgements}

Funding from the Romanian Government (Partnership Project Metafore, Contract 107/2014 by UEFISCDI of Bucharest) is gratefully acknowledged. The authors appreciate so much the work of anonymous reviewers.

\section{References}

1. Ciornea, E.; Boz, I.; Ionel, E.; Cojocaru, S.I.; Dumitru, G. The biochemical and histoanatomical response of some woody species to anthropic impact in Suceava County, Romania. Turk. J. Biol. 2015, 39(4), 624-637.

2. Iacoban, C.; Risca, I.M.; Roibu, C.; Ciornea, E.T.; Necula, R.; Ilieva, D., Sandu I., Drochioiu, G. Tarnita Polluted Area: Accumulation of Heavy Metals and Nutrients from the Soil by Woody Species. Rev. Chim. 2019, 70(3), 753-758. 
3. Stumbea, D. Preliminaries on pollution risk factors related to mining and ore processing in the $\mathrm{Cu}$-rich pollymetallic belt of Eastern Carpathians, Romania. Environ Sci. Pollut. R 2013, 20(11), 7643-7655.

4. Frost, R.L.; Kloprogge, T.; Weier, M.L.; Martens, W.N.; Ding, Z.; Edwards, H.G. Raman spectroscopy of selected arsenates-implications for soil remediation. Spectrochim. Acta A 2003, 59, 2241-2246.

5. Parga, J.R.; Cocke, D.L.; Valenzuela, J.L.; Gomes, J.A.; Kesmez, M.; Irwin, G.; Weir, M. Arsenic removal via electrocoagulation from heavy metal contaminated groundwater in La Comarca Lagunera Mexico. J. Hazard. Mater. 2005, 124(1-3), 247-254.

6. Ratnaike, R.N. Acute and chronic arsenic toxicity. Postgrad. Med. J. 2003, 79, 391-396.

7. Flora, S.J.S.; Bhadauria, S.; Kannan, G.M.; Singh, N. Arsenic induced oxidative stress and the role of antioxidant supplementation during chelation: a review. J. Environ. Biol. 2007, 28(2), 333-347.

8. Dahal, B.M.; Fuerhacker, M.; Mentler, A.; Karki, K.B.; Shrestha, R.R.; Blum, W.E.H. Arsenic contamination of soils and agricultural plants through irrigation water in Nepal. Environ. Pollut. 2008, 155(1), 157163.

9. Rahman, S.; Hossain, F. A forensic look at groundwater arsenic contamination in Bangladesh. Environ. Forensics. 2008, 9(4), 364-374.

10. Wang, P.; Wang, S.; Liu, S.; Li Y.; He M.; Lin, C. Occurrence, speciation, source and geochemical cycle of arsenic. Environ. Sci. Techn. China. 2010, 33(7), 90-97.

11. Geng, C.N.; Zhu, Y.G.; Tong, Y.P.; Smith, S.E.; Smith, F.A. Arsenate (As) uptake by and distribution in two cultivars of winter wheat (Triticum aestivum L.). Chemosphere 2006, 62(4), 608-615.

12. Tripathi R.D.; Tripathi P.; Dwivedi S.; Dubey S.; Chatterjee S.; Chakrabarty D.; Trivedi P. K. Arsenomics: omics of arsenic metabolism in plants. Front Physiol. 2012, 3, 275.

13. Kumar, S.; Trivedi, P.K. Genomics of arsenic stress response in plants. In Genetic enhancement of crops for tolerance to abiotic stress: mechanisms and approaches. Vol. I, Springer, Cham. 2019, pp. 231248. 
14. Liu, X.; Zhang, S.; Shan, X.; Zhu, Y.G. Toxicity of arsenate and arsenite on germination, seedling growth and amylolytic activity of wheat. Chemosphere 2005, 61, 293-301.

15. Stefanescu, R.; Butnariu, A.E.; Zamfirache, M.M.; Surleva, A.; Ciobanu, C.I.; Pintilie, O.; Drochioiu, G. Yeast-based microbiological decontamination of heavy metal contaminated soils of Tarnita. Carpath. J. Earth Environ. 2017, 12(1), 153-159.

16. Hughes, M.F. Arsenic toxicity and potential mechanisms of action. Toxicol. Lett. 2002, 133(1), 1-16.

17. Weiss, Y.; Rubin, B.; Shulman, A.; Shir, I.B.; Keinan, E.; Wolf, S. Determination of plant resistance to carbamate herbicidal compounds inhibiting cell division and early growth by seed and plantlets bioassays. Nat. Protoc. 2006, 1, 2282-2287.

18. Barbu, C.H.; Sand, C. Teoria şi practica modernă a remedierii solurilor poluate cu metale grele (Modern theory and practice in remediation of heavy metals polluted soils-from Romanian), Alma Mater, Sibiu. 2004, 64-66.

19. Snedecor, G.V. Statistical methods applied to experiments in agriculture and biology. The Iowa State Univ. Press, U.S.A. 1994, 255-274. 